Prepared in cooperation with the U.S. Fish and Wildlife Service, Region 1

Determination of Diphacinone in Seawater, Vertebrates, Invertebrates, and Bait Pellet Formulations Following Aerial Broadcast on Mokapu Island, Molokai, Hawai'i

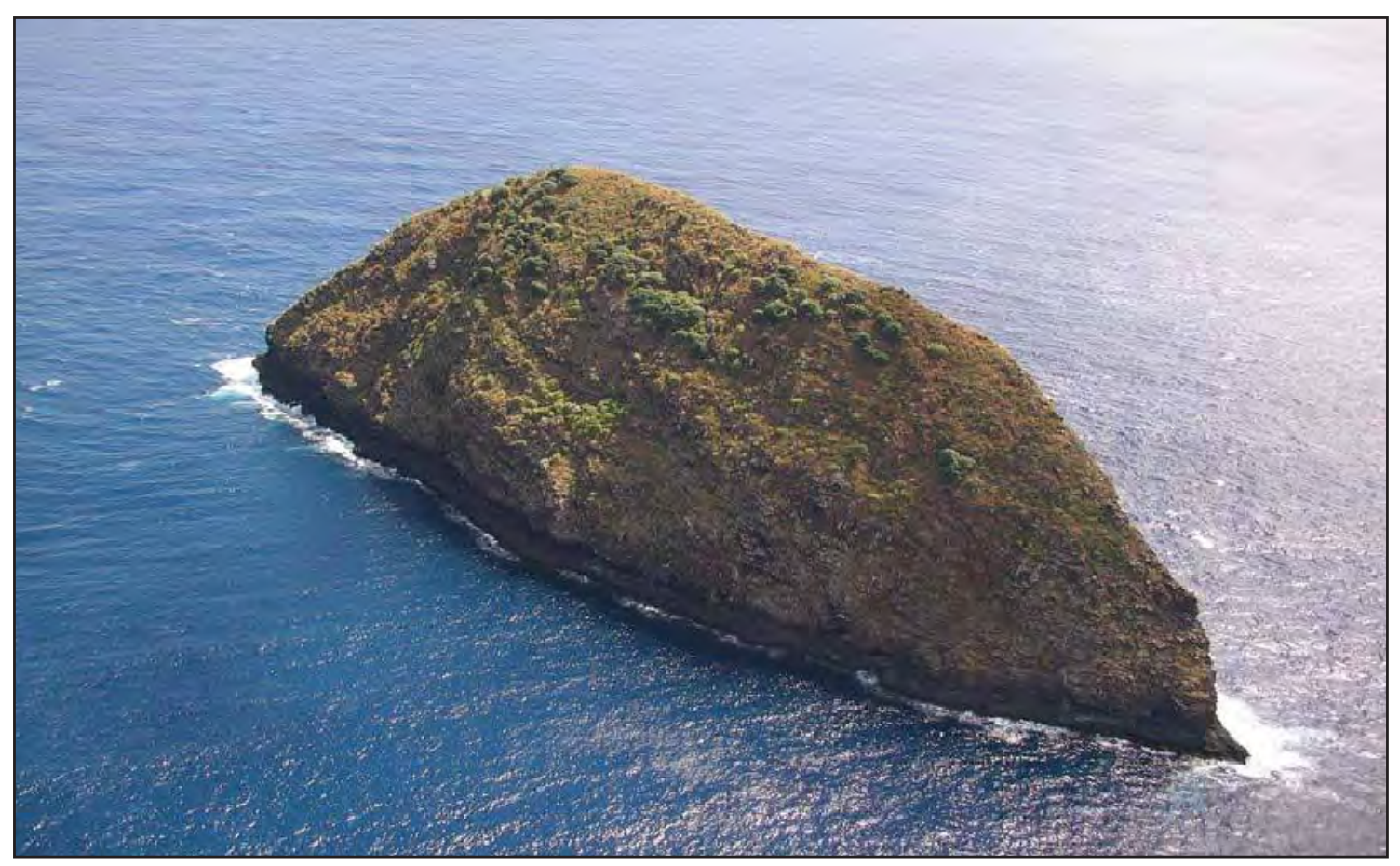

Open-File Report 2008-1285 
Cover. Aerial photograph of Mokapu Island, Molokai, Hawai'i (Photo by C. Swenson, U.S. Fish and Wildlife Service). 


\section{Determination of Diphacinone in Sea Water, Vertebrates, Invertebrates, and Bait Pellet Formulations Following Aerial Broadcast on Mokapu Island, Molokai, Hawai'i}

By Robert W. Gale, Michael Tanner, Carl E. Orazio

Prepared in cooperation with the U.S. Fish and Wildlife Service, Region 1

Open-File Report 2008-1285 


\section{U.S. Department of the Interior DIRK KEMPTHORNE, Secretary}

\section{U.S. Geological Survey \\ Mark D. Myers, Director}

\section{U.S. Geological Survey, Reston, Virginia: 2008}

For product and ordering information:

World Wide Web: http://www.usgs.gov/pubprod

Telephone: 1-888-ASK-USGS

For more information on the USGS--the Federal source for science about the Earth, its natural and living resources, natural hazards, and the environment:

World Wide Web: http://www.usgs.gov

Telephone: 1-888-ASK-USGS

Any use of trade, product, or firm names is for descriptive purposes only and does not imply endorsement by the U.S. Government.

Although this report is in the public domain, permission must be secured from the individual copyright owners to reproduce any copyrighted materials contained within this report.

Suggested citation:

Gale, R.W., Tanner, M., and Orazio, C.E., 2008, Determination of diphacinone in sea water, vertebrates, invertebrates, and bait pellet formulations following aerial broadcast on Mokapu Island, Molokai, Hawai'i: U.S. Geological Survey Open-File Report 2008-1285, 16 p. 


\section{Contents}

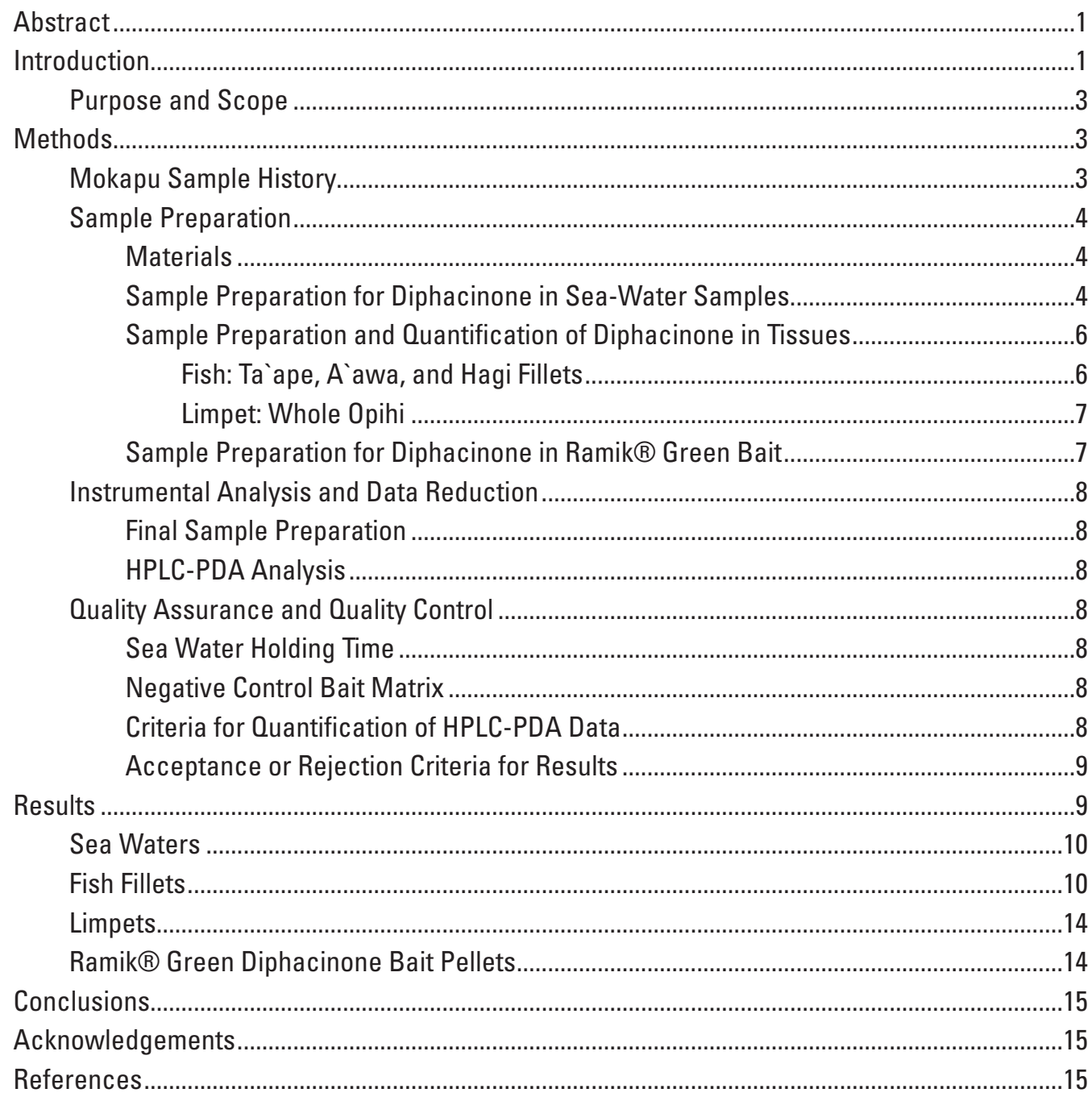

\section{Figures}

1. Screen shot of Mokapu, Island, Molokai, Hawai'i ............................................................

2. Aerial photograph of Mokapu Island, Molokai, Hawai'i.....................................................2

3. Chart showing preparatory methods for diphacinone in the various matrices ................6

4-5. Graphs showing-

4. High performance liquid chromatography-photodiode array (HPLC-PDA) chromatogram of diphacinone...

5. Photodiode array (PDA) spectrum of diphacinone ...................................................10 


\section{Tables}

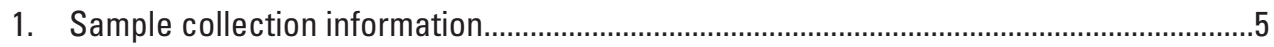

2. Quality-control sample types for analysis of environmental samples............................11

3. Quality-control sample types and levels selected for study ...........................................11

4. Diphacinone concentrations in sea water .........................................................................12

5. Diphacinone concentrations in fish fillets........................................................................13

6. Diphacinone concentrations in whole Opihi limpets.......................................................14

7. Diphacinone concentrations in Ramik $®$ Green bait lot composites ...............................15

\section{Conversion Factors}

\begin{tabular}{|c|c|c|}
\hline Multiply & By & To obtain \\
\hline \multicolumn{3}{|c|}{ Length } \\
\hline meter (m) & 0.3048 & feet $(\mathrm{ft})$ \\
\hline kilometer $(\mathrm{km})$ & 0.621388 & mile (mi) \\
\hline nanometer $(\mathrm{nm})$ & $=$ & $10^{-9}$ meter \\
\hline \multicolumn{3}{|c|}{ Volume } \\
\hline microliter $(\mu \mathrm{L})$ & 0.00003382 & ounce, fluid (fl. oz) \\
\hline milliliter (mL) & 0.03382 & ounce, fluid (fl. oz) \\
\hline liter $(\mathrm{L})$ & 33.82 & ounce, fluid (fl. oz) \\
\hline \multicolumn{3}{|c|}{ Mass } \\
\hline $\operatorname{gram}(\mathrm{g})$ & 0.03527 & ounce, avoirdupois (oz) \\
\hline microgram $(\mu \mathrm{g})$ & $=$ & $1 \times 10^{-6}$ grams \\
\hline nanogram (ng) & $=$ & $1 \times 10^{-9}$ grams \\
\hline \multicolumn{3}{|c|}{ Concentration } \\
\hline $\operatorname{molar}(\mathrm{M})$ & $=$ & moles per liter \\
\hline millimolar (mM) & $=$ & millimoles per liter $\left(10^{-3} \mathrm{M}\right)$ \\
\hline micromolar $(\mu \mathrm{M})$ & $=$ & micromoles per liter $\left(10^{-6} \mathrm{M}\right)$ \\
\hline microgram per gram $(\mu \mathrm{g} / \mathrm{g})$ & $=$ & part per million (ppm: $10^{6}$ ) \\
\hline nanogram per gram (ng/g) & $=$ & part per billion $\left(\mathrm{ppb} ; 10^{9}\right)$ \\
\hline microgram per milliliter $(\mu \mathrm{g} / \mathrm{mL})$ & $=$ & part per million (ppm: $10^{6}$ ) \\
\hline microgram per liter $(\mu \mathrm{g} / \mathrm{L})$ & $=$ & part per billion (ppb: $10^{9}$ ) \\
\hline nanogram per milliliter $(\mathrm{ng} / \mathrm{mL})$ & $=$ & part per billion $\left(\mathrm{ppb} ; 10^{9}\right)$ \\
\hline nanogram per liter $(\mathrm{ng} / \mathrm{L})$ & $=$ & part per trillion (pptr; $10^{12}$ ) \\
\hline \multicolumn{3}{|c|}{ Application rate } \\
\hline pounds per acre (lb/acre) & 1.125 & kilograms per hectare $(\mathrm{kg} / \mathrm{ha})$ \\
\hline \multicolumn{3}{|c|}{ Electrical resistance } \\
\hline mega-ohms $(\mathrm{m} \Omega)$ & $=$ & $10^{6} \mathrm{ohms}$ \\
\hline
\end{tabular}

Temperature in degrees Celsius $\left({ }^{\circ} \mathrm{C}\right)$ may be converted to degrees Fahrenheit $\left({ }^{\circ} \mathrm{F}\right)$ as follows:

$$
{ }^{\circ} \mathrm{F}=\left(1.8 \times{ }^{\circ} \mathrm{C}\right)+32
$$

Concentrations of chemical constituents in solid materials (tissues) are given in nanogram per gram (ng/g, or parts per billion, ppb). Concentrations of chemical constituents in calibration standard solutions and in liquid samples (sea water) are given in nanograms per milliliter (ng/mL, or parts per billion, ppb). 


\title{
Determination of Diphacinone in Sea Water, Vertebrates, Invertebrates, and Bait Pellet Formulations Following Aerial Broadcast on Mokapu Island, Molokai, Hawai'i
}

\author{
By Robert W. Gale, Michael Tanner, and Carl E. Orazio
}

\begin{abstract}
This report presents the results of a study to determine diphacinone concentrations in samples of sea water and in fillet samples of fish and in limpets from the ocean adjacent to Mokapu Island and from reference samples from Molokai, Hawai'i; concentrations of the active ingredient (diphacinone) were also determined in samples of the Ramik ${ }^{\circledR}$ Green bait pellets used for the broadcast study. After preparation, diphacinone concentrations were determined with high-performance liquid chromatography with photodiode array detection. No detectable concentrations of diphacinone were found in the fish, limpets, or sea-water samples from Mokapu Island or from the reference sites. The limit of detection for diphacinone in sea water was 90 nanograms per liter (parts per trillion); the limit of detection in fish fillets was 10 nanograms per gram (parts per billion); and the limit of detection in limpets was 17 nanograms per gram. The average concentration of diphacinone in the Ramik $®$ Green bait pellets was 45 micrograms per gram (parts per million), which represents 90 percent of the nominal concentration stated for the product by the manufacturer.
\end{abstract}

\section{Introduction}

Oceanic islands contain a disproportionate share of the world's unique terrestrial species and are especially vulnerable to the impacts of invasions by nonnative species, including rats. More than 80 percent of all oceanic islands worldwide have been infested by some species of invasive rodent. The ecosystems on oceanic islands are extremely susceptible to disturbances caused by infestations of invasive species because of their limited habitat coverage and the close integration of niche species. Most species extinction events that have occurred or are occurring in these isolated ecosystems are caused by invasive species. Many island rodent eradication projects have been successfully conducted worldwide using anticoagulant rodenticides.
Mokapu is an approximately 10-acre island located approximately 1 kilometer $(\mathrm{km})$ off the north coast of Molokai just east of the Kalaupapa Peninsula (figs. 1 and 2). The island is a Hawai'i State Seabird Sanctuary managed by the Hawai'i Department of Land and Natural Resources, Division of Forestry and Wildlife (DOFAW); the island supports native populations of white-tailed tropicbirds (Phaethon lepturus), red-tailed tropicbirds (P. rubricauda), black noddies (Anous minutus), and wedge-tailed shearwaters (Puffinus pacificus). Like the nearby islands of Okala and Huelo, Mokapu supports some of the most diverse native coastal plant communities in Hawai'i. For example, Mokapu contains 29 native plant species; several of these species are rare and vulnerable to extinction. The island is dominated by native shrubs, but retains small groves of native lama trees (Diospyros spp.), some native palm trees (Pritchardii hillebrandii), which dominate nearby Huelo, and 11 of the last 14 individuals of the shrub Pittosporum halophilum that is endemic to Molokai. Peucedanum sandwicense, a large perennial herbaceous plant, is listed as threatened under the Endangered Species Act of 1973, and Lepidium bidentatum var. o-waihiense, a succulent herbaceous plant, also is a species of concern on the island. In 2003, the U.S. Fish and Wildlife Service (USFWS) designated Mokapu Island as critical habitat for $P$. sandwicense and Tetramolopium rockii (perennial shrubs) and Brighamia rockii, a succulent perennial plant present on nearby adjacent islands.

It is extremely likely that the presence of rats has terminated or slowed the recruitment of the threatened Peucedanum sandwicense as well as Pritchardia, Pittosporum, and Diospyros along with other native plant taxa on Mokapu. Rats are known to eat Pritchardia seeds, and their presence on Mokapu is believed to be contributing to the decline of this rare, endemic species. In 2006, only 12 mature Pritchardia palms and one seedling were present on Mokapu.

Likewise, only 11 individuals of Pittosporum, 20 individuals of Peucedanum, and two small groves of Diospyros remain on Mokapu. In addition, observations from other Pacific islands document that rats depredate eggs, and sometimes prey upon the young and adults of three of the seabird species known to nest on Mokapu: red-tailed and white-tailed 


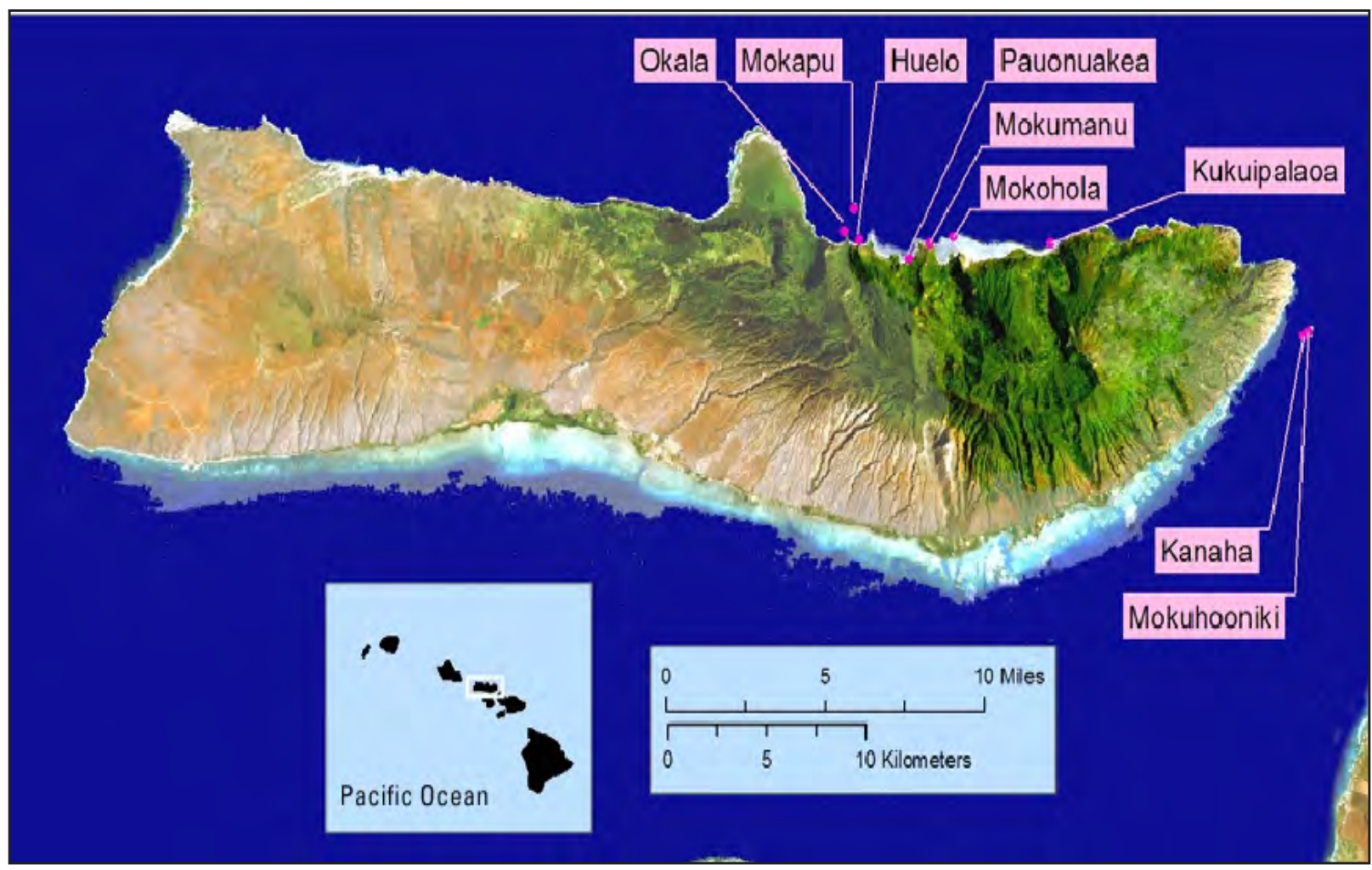

Figure 1. Screen shot of Mokapu, Island, Molokai, Hawai'i (courtesy of GoogleEarth@).

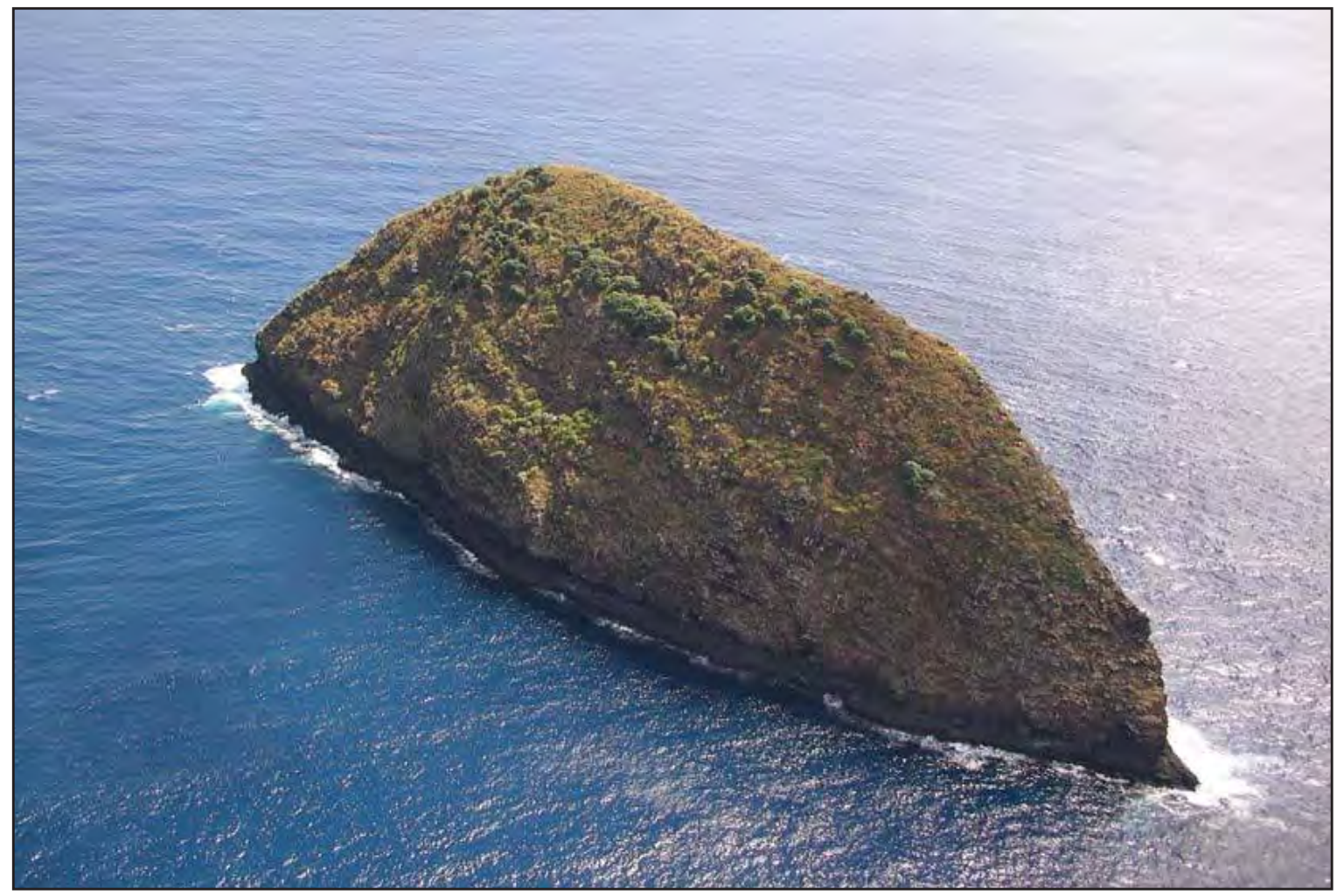

Figure 2. Aerial photograph of Mokapu Island, Molokai, Hawai'i. (Photo by C. Swenson, U.S. Fish and Wildlife Service). 
tropicbirds and wedge-tailed shearwaters; therefore, rodent control is a critical management objective for maintaining and/ or restoring the ecological integrity of Mokapu Island.

Diphacinone is a chronic anticoagulant rodenticide that acts by disrupting the normal blood clotting mechanisms of vertebrates; competing at receptor sites in the liver with vitamin K, a necessary chemical for blood clotting. Diphacinone has been shown to be an effective toxicant for rats in Hawai'i and elsewhere. It is efficacious, yet has relatively low risk of impacts to nontarget species through consumption of bait pellets (direct impacts) and/or through consumption of prey that have consumed the bait pellets (secondary impacts).

The USFWS, the DOFAW, and the U.S. Department of Agriculture, Animal and Plant Health Inspection Service, Wildlife Services (USDA-APHIS-WS) proposed to eradicate Polynesian rats from Mokapu Island using the anticoagulant rodenticide diphacinone ( 0.005 percent active ingredient) applied by aerial broadcast. Operations were conducted only during the winter months (December through March) when alternate rat foods and rat populations are lowest and migratory native nontarget species were not present, or were present only in low numbers.

Toxic bait pellets containing the active ingredient diphacinone at 50 parts per million (ppm) were used to exterminate rats. The bait is dyed green by the manufacturer to reduce dietary exposure to birds. The rodenticide was broadcast uniformly across the emergent land area of the island at the approved application rate in an attempt to expose all rats to a lethal dose. Applications were completed by aerial broadcast across 100 percent of the land area of the island at a nominal rate of 10 pounds per acre (lb/acre) in two separate broadcast applications on February 6 and February 12, 2008. Coastlines and steep areas were treated with twice the rodenticide for each application.

Monitoring for primary and secondary adverse impacts of diphacinone on nontarget species was one of the foremost concerns for this rodent eradication project. Populations of desired nontarget species, including nesting seabirds and protected plants, were monitored actively for a sufficient period (approximately 2 years) to produce reliable population estimates of adverse impacts before and after rodenticide treatments. The preceding text was condensed from Swenson and Duvall, 2007.

This report presents the development of analytical chemistry methods for determining diphacinone concentrations in sea water, fish tissues, and limpets, and the quantification of diphacinone concentrations in these samples after application of the rodenticide to Mokapu Island. Sea water, fish, and limpets from Kalaupapa National Historical Park and from commercial sources were used as negative control (reference) samples. The results are intended to provide the program managers and other resource managers in the study area with reference data regarding the fate and effects of diphacinone on Mokapu Island. Additionally, the procedures developed for the various matrices could serve as prototypes for the develop- ment of similar methods on other matrices where diphacinone contamination may be an issue in the future.

\section{Purpose and Scope}

The objectives of this study were to assess the levels of diphacinone present in sea water and biota as a consequence of aerial broadcast of Ramik Green ${ }^{\circledR}$ rodenticide to exterminate Polynesian rats from Mokapu Island. These results will serve as a demonstration of the actual risk of exposure of non-target organisms to the use of diphacinone in the proposed rodent eradication strategy. The study consisted of several analytical sample sets, each addressing the post-broadcast diphacinone exposure levels in the immediate environment.

\section{Methods}

\section{Mokapu Sample History}

Personnel from the USFWS, DOFAW, and/or USDAAPHIS-WS collected grab samples of reference sea water on January 23, 2008, at Kalaupapa National Historical Park (Ka Laea Point) for diphacinone analysis. Aerial broadcasts of Ramik® Green rodenticide bait were conducted on February 6 and February 12, 2008. On February 17, after aerial broadcasts were completed, sea-water samples were collected from several points surrounding Mokapu Island for diphacinone analysis.

Following aerial broadcast of Ramik® Green, surface water grab samples were collected within $30 \mathrm{feet}(\mathrm{ft})$ of the eastern and western sides of Mokapu Island. Six 250 milliliter $(\mathrm{mL})$ samples were collected at each of the six stations. Three stations were located off the eastern shore and three off the western shore. Parts of each sample were shipped cold $\left[4{ }^{\circ} \mathrm{Celsius}\left({ }^{\circ} \mathrm{C}\right)\right]$ to the U.S. Geological Survey (USGS) and the other participating laboratories using chain of custody protocols. Two samples from each site were provided to the USGS for analysis. An additional experiment was incorporated to validate the effect of holding time for the analysis of diphacinone in sea-water samples (stored at $4{ }^{\circ} \mathrm{C}$ for 53 days).

Diphacinone was determined in invertebrates (limpets) and vertebrates (fish) from reference sites and from Mokapu Island following aerial broadcast of Ramik® Green to quantify reference and post-broadcast diphacinone levels. Personnel from the USFWS, DOFAW, and/or USDA-APHIS-WS collected one species of mollusk (Opihi, the Hawai'ian Limpet) from a reference location (Kalaupapa) and from Mokapu sites after aerial broadcast on February 17, 2008. Six individual fish samples (duplicate samples of three separate species, i.e. Ta`ape, A`awa, and Hagi) were collected from within $50 \mathrm{ft}$ of the western shore of Mokapu on February 17, 2008, following aerial broadcast. Reference samples of Ta`ape were purchased from a commercial Oahu market. Fish and limpet samples were packaged in aluminum foil packets sealed in 
zip-lock bags and stored frozen. Whole limpet carcasses and fillet portions of each fish were shipped frozen to the participating laboratories under chain of custody on March 17, 2008 (table 1).

The diphacinone content of Ramik® Green rodenticide bait samples stored at the Maui DOFAW base yard and subsequently used in the rat eradication efforts on Mokapu Island, Hawai' $i$, was verified. Personnel from the USFWS, DOFAW and/or USDA-APHIS-WS collected 10 random Ramik® Green rodenticide bait samples from the Maui DOFAW base yard on February 12, 2008. Parts [ 30 2-gram (g) pellets] of each sample were shipped frozen to the participating laboratories under chain of custody, and were received by March 17, 2008 (table 1).

Upon receipt at the USGS, the sea-water samples were logged in to the sample data-base system, assigned a unique identification number, and stored refrigerated at $4{ }^{\circ} \mathrm{C}$ until analysis. The tissue and bait samples were logged and stored in the dark at $-20^{\circ} \mathrm{C}$ until analysis.

\section{Sample Preparation}

Sample preparation methods for diphacinone are matrixdependent and were developed for each target matrix: sea water, fillet, whole limpet, and bait. The general method consisted of extraction of diphacinone from the matrix of interest, and subsequent concentration and purification of the extract by solid-phase extraction (SPE) or low performance sizeexclusion chromatography (LP-SEC). The general schemes developed are presented in figure 3 .

Analytical separation of diphacinone was performed by high performance liquid chromatography (HPLC) followed by ultraviolet-visible photodiode array absorbance (PDA) detection and quantification after the methods of Yang and others (2001). Coumarin was used as the instrumental internal standard.

\section{Materials}

Solid-phase extraction cartridges [Oasis-HLB (hydrophilic/lipophilic balance) $6 \mathrm{~mL}$ x 500 milligrams (mg)] were purchased from Waters Corp., Milford, Massachusetts. Octadecyl SPE cartridges [Isolute C18(EC) $6 \mathrm{~mL}$ x $1 \mathrm{~g}$ ] were purchased from International Sorbent Technology, Mid Glamorgan, United Kingdom. The size exclusion material (SX-3 biobeads 200-400 mesh) was purchased from Bio-Rad Co. Richmond, California. Acetone, acetonitrile, dichloromethane, methanol (OPTIMA grade), acetic acid (HPLC-grade), anhydrous sodium sulfate, ascorbic acid (reagent grade), and $2 \mathrm{~N} o$-phosphoric acid were purchased from Fisher Scientific, Fair Lawn, New Jersey. Whatman 0.45 micrometer $(\mu \mathrm{m})$ polytetrafluoroethylene (PTFE) syringe filters were purchased from Whatman, Inc., Sanford, Maine. Tetrabutylammonium hydroxide (TBAH) was purchased from Sigma-Aldrich, St. Louis, Missouri. Tetrabutylammonium phosphate (TBAP) was purchased from ACROS Organics, Somerville, New Jersey. Diphacinone and coumarin standard solutions (in methanol) were purchased from AccuStandard, New Haven, Connecticut. Milli-Q water [18 mega-ohms (m $\Omega$ ), Millipore Synergy UV, Millipore Corp., Bedford, Massachusetts] was used throughout the analytical process.

Aqueous tetrabutylammonium hydroxide ion pair (TBAHIP) solutions used for HPLC and for SPE were prepared at 0.1 molar (M) and $0.03 \mathrm{M}$ in water and $\mathrm{pH}$ adjusted to 6.0 with $o$-phosphoric acid. Solid TBAP (not $\mathrm{pH}$ adjusted) was used to prepare the methanolic 5 millimolar (mM) tetrabutylammonium phosphate solution used for the bait refluxextractions.

\section{Sample Preparation for Diphacinone in Sea- Water Samples}

Diphacinone has a water solubility of $30 \mathrm{ppm}$ and is subject to hydrolysis at $\mathrm{pH} 5$ or less; however, it is stable to hydrolysis from pH 7 to 9 (U.S. Environmental Protection Agency, 1998). The sea-water samples collected for this study were stored refrigerated at $4{ }^{\circ} \mathrm{C}$ and in the dark for 53 days before analysis. The samples were collected on February 17, 2008, shipped to USGS on March 17, 2008, and extracted on April 10, 2008, following method development and validation. The storage stability of diphacinone in sea water for a similar period was investigated to ensure that the holding time for diphacinone was not exceeded. A $200 \mathrm{~mL}$ aliquot of Kalaupapa reference sea water $(\mathrm{pH} 8.1)$ was fortified with about 5 micrograms $(\mu \mathrm{g})$ of diphacinone and was returned to refrigerated storage to simulate the holding times for the samples. Another $200 \mathrm{~mL}$ volume of Kalaupapa reference sea water ( $\mathrm{pH}$ 8.1) was fortified with about $5 \mu \mathrm{g}$ diphacinone at the time of analysis to determine recovery efficiency. The storage stability sample was analyzed on May 19, 2008 (53 days post fortification), using the methods described for sea-water samples.

A solid phase extraction method was developed for the isolation of diphacinone from sea water. Although the isolation of diphacinone from coconut crab (Birgus latro) tissues is well understood (Tanner and Orazio, written commun., 2008), no work has been reported to assess the recovery of diphacinone from sea water. Generally, the water samples were extracted by an appropriate SPE cartridge to adsorb diphacinone that was then recovered by elution of the SPE and quantified by HPLC with PDA detection. Potential matrix effects from salts on recovery of diphacinone from the SPE sorbent or the retention of diphacinone were investigated and determined to be negligible.

The $\mathrm{pH}$ of the Mokapu Island water samples was determined using a Mettler-Toledo Seven Easy pH meter (Schwerzenbach, Inc., Switzerland). The $\mathrm{pH}$ meter was calibrated with 4.00 and 7.00 buffer solutions (Fisher Scientific, Fair Lawn, New Jersey) before $\mathrm{pH}$ determinations. Fortified samples were prepared using $200 \mathrm{~mL}$ of Kalaupapa reference sea water or 
Table 1. Sample collection information.

[USGS, U.S. Geological Survey; ID, identification; mL, milliliter; Al, aluminum; g, gram]

\begin{tabular}{|c|c|c|c|c|c|c|c|}
\hline $\begin{array}{l}\text { Collection } \\
\text { date }\end{array}$ & $\begin{array}{l}\text { USGS } \\
\text { ID }\end{array}$ & Site & Sample description & Sample type & $\begin{array}{l}\text { Sample } \\
\text { container }\end{array}$ & Amount & Notes \\
\hline $1 / 23 / 2008$ & 42033 & $\begin{array}{l}\text { Kalaupapa National Historical } \\
\text { Park (at Ka Laea Point), } \\
\text { Molokai }\end{array}$ & Sea water & Water & $\begin{array}{l}\text { 250-mL wide- } \\
\text { mouth jars }\end{array}$ & $3 \times 250 \mathrm{~mL}$ & $\begin{array}{l}\text { Reference site; } \\
\text { white lids } \\
\text { letter "R" }\end{array}$ \\
\hline $1 / 23 / 2008$ & 42034 & $\begin{array}{l}\text { Kalaupapa National Historical } \\
\text { Park (at Ka Laea Point), } \\
\text { Molokai }\end{array}$ & Limpet, Opihi (Cellata exarata) & Whole organism (incl. shell) & Al-foil/Ziploc & 3 individuals—about $10 \mathrm{~g}$ each & Reference site \\
\hline $3 / 17 / 2008$ & 42035 & Oahu Commercial Fish Market & Blue-lined Snapper, Ta`ape (Lutjanus kasmira) & Skin-on fillet & Al-foil/Ziploc & 4 individuals—about $50 \mathrm{~g}$ each & Reference site \\
\hline 2/17/2008 & 42036 & Mokapu Station 1 & Sea water & Water & $\begin{array}{l}\text { 250-mL wide- } \\
\text { mouth jars }\end{array}$ & $2 \times 250 \mathrm{~mL}$ & Site 1 of 6 \\
\hline $2 / 17 / 2008$ & 42037 & Mokapu Station 2 & Sea water & Water & $\begin{array}{c}\text { 250-mL wide- } \\
\text { mouth jars }\end{array}$ & $2 \times 250 \mathrm{~mL}$ & Site 2 of 6 \\
\hline 2/17/2008 & 42038 & Mokapu Station 3 & Sea water & Water & $\begin{array}{c}250-\text { mL wide- } \\
\text { mouth jars }\end{array}$ & $2 \times 250 \mathrm{~mL}$ & Site 3 of 6 \\
\hline $2 / 17 / 2008$ & 42039 & Mokapu Station 4 & Sea water & Water & $\begin{array}{l}\text { 250-mL wide- } \\
\text { mouth jars }\end{array}$ & $2 \times 250 \mathrm{~mL}$ & Site 4 of 6 \\
\hline $2 / 17 / 2008$ & 42040 & Mokapu Station 5 & Sea water & Water & $\begin{array}{l}\text { 250-mL wide- } \\
\text { mouth jars }\end{array}$ & $2 \times 250 \mathrm{~mL}$ & Site 5 of 6 \\
\hline $2 / 17 / 2008$ & 42041 & Mokapu Station 6 & Sea water & Water & $\begin{array}{l}250-\text { mL wide- } \\
\text { mouth jars }\end{array}$ & $2 \times 250 \mathrm{~mL}$ & Site 6 of 6 \\
\hline $2 / 17 / 2008$ & 42042 & Mokapu Station 1 & Limpet, Opihi (Cellata exarata) & Whole organism (without shell) & Al-foil/Ziploc & $\sim 4$ individuals—about $10 \mathrm{~g}$ total & Site 1 of 3 \\
\hline $2 / 17 / 2008$ & 42043 & Mokapu Station 2 & Limpet, Opihi (Cellata exarata) & Whole organism (without shell) & Al-foil/Ziploc & $\sim 4$ individuals—about $10 \mathrm{~g}$ total & Site 2 of 3 \\
\hline $2 / 17 / 2008$ & 42044 & Mokapu Station 3 & Limpet, Opihi (Cellata exarata) & Whole organism (without shell) & Al-foil/Ziploc & $\sim 4$ individuals—about $10 \mathrm{~g}$ total & Site 3 of 3 \\
\hline 2/17/2008 & 42045 & Mokapu Station 1-A & Blue-lined Snapper, Ta`ape (Lutjanus kasmira) & Skinless fillet & Al-foil/Ziploc & 1 individual—about $50 \mathrm{~g}$ & Site 1 Fish-1 \\
\hline $2 / 17 / 2008$ & 42046 & Mokapu Station 1-B & Blue-lined Snapper, Ta`ape (Lutjanus kasmira) & Skinless fillet & Al-foil/Ziploc & 1 individual—about $50 \mathrm{~g}$ & Site 1 Fish-2 \\
\hline 2/17/2008 & 42047 & Mokapu Station 1-C & Blue-lined Snapper, Ta`ape (Lutjanus kasmira) & Skinless fillet & Al-foil/Ziploc & 1 individual—about $50 \mathrm{~g}$ & Site 1 Fish-3 \\
\hline $2 / 17 / 2008$ & 42048 & Mokapu Station 1-D & Blue-lined Snapper, Ta`ape (Lutjanus kasmira) & Skinless fillet & Al-foil/Ziploc & 1 individual—about $50 \mathrm{~g}$ & Site 1 Fish-4 \\
\hline $2 / 17 / 2008$ & 42049 & Mokapu Station -E & Hogfish, A`awa (Bodianus bilunulatus) & Skinless fillet & Al-foil/Ziploc & 1 individual—about $50 \mathrm{~g}$ & Site 1 Fish-5 \\
\hline $2 / 17 / 2008$ & 42050 & Mokapu Station 1-F & Bridled triggerfish, Hagi (Sufflamen fraenatus) & Skinless fillet & Al-foil/Ziploc & 1 individual—about $50 \mathrm{~g}$ & Site 1 Fish-6 \\
\hline 2/17/2008 & 42051 & Maui-1 & Ramik@ Green (diphacinone bait pellets) & Individual box of pellets \#1 & Ziploc & $\sim 25-30$ pellets $30 \mathrm{~g}$ & Box 1:2 \\
\hline $2 / 17 / 2008$ & 42052 & Maui-2 & Ramik ${ }^{\circledR}$ Green (diphacinone bait pellets) & Individual box of pellets \#2 & Ziploc & $\sim 25-30$ pellets $30 \mathrm{~g}$ & Box $2: 2$ \\
\hline $2 / 17 / 2008$ & 42053 & Maui-3 & Ramik@ Green (diphacinone bait pellets) & Individual box of pellets \#3 & Ziploc & $\sim 25-30$ pellets $30 \mathrm{~g}$ & Box 3:2 \\
\hline 2/17/2008 & 42054 & Maui-4 & Ramik@ Green (diphacinone bait pellets) & Individual box of pellets \#\$ & Ziploc & $\sim 25-30$ pellets $30 \mathrm{~g}$ & Box 4:2 \\
\hline $2 / 17 / 2008$ & 42055 & Maui-5 & Ramik@ Green (diphacinone bait pellets) & Individual box of pellets \#5 & Ziploc & $\sim 25-30$ pellets $30 \mathrm{~g}$ & Box 5:2 \\
\hline $2 / 17 / 2008$ & 42056 & Maui-6 & Ramik ${ }^{\circledR}$ Green (diphacinone bait pellets) & Individual box of pellets \#6 & Ziploc & $\sim 25-30$ pellets $30 \mathrm{~g}$ & Box $6: 2$ \\
\hline $2 / 17 / 2008$ & 42057 & Maui-7 & Ramik@ Green (diphacinone bait pellets) & Individual box of pellets \#7 & Ziploc & $\sim 25-30$ pellets $30 \mathrm{~g}$ & Box 7:2 \\
\hline $2 / 17 / 2008$ & 42058 & Maui-8 & Ramik® Green (diphacinone bait pellets) & Individual box of pellets \#8 & Ziploc & $\sim 25-30$ pellets $30 \mathrm{~g}$ & Box 8:2 \\
\hline 2/17/2008 & 42059 & Maui-9 & Ramik@ Green (diphacinone bait pellets) & Individual box of pellets \#9 & Ziploc & $\sim 25-30$ pellets $30 \mathrm{~g}$ & Box 9:2 \\
\hline $2 / 17 / 2008$ & 42060 & Maui-10 & Ramik® Green (diphacinone bait pellets) & Individual box of pellets \#10 & Ziploc & $\sim 25-30$ pellets $30 \mathrm{~g}$ & Box 10:2 \\
\hline
\end{tabular}



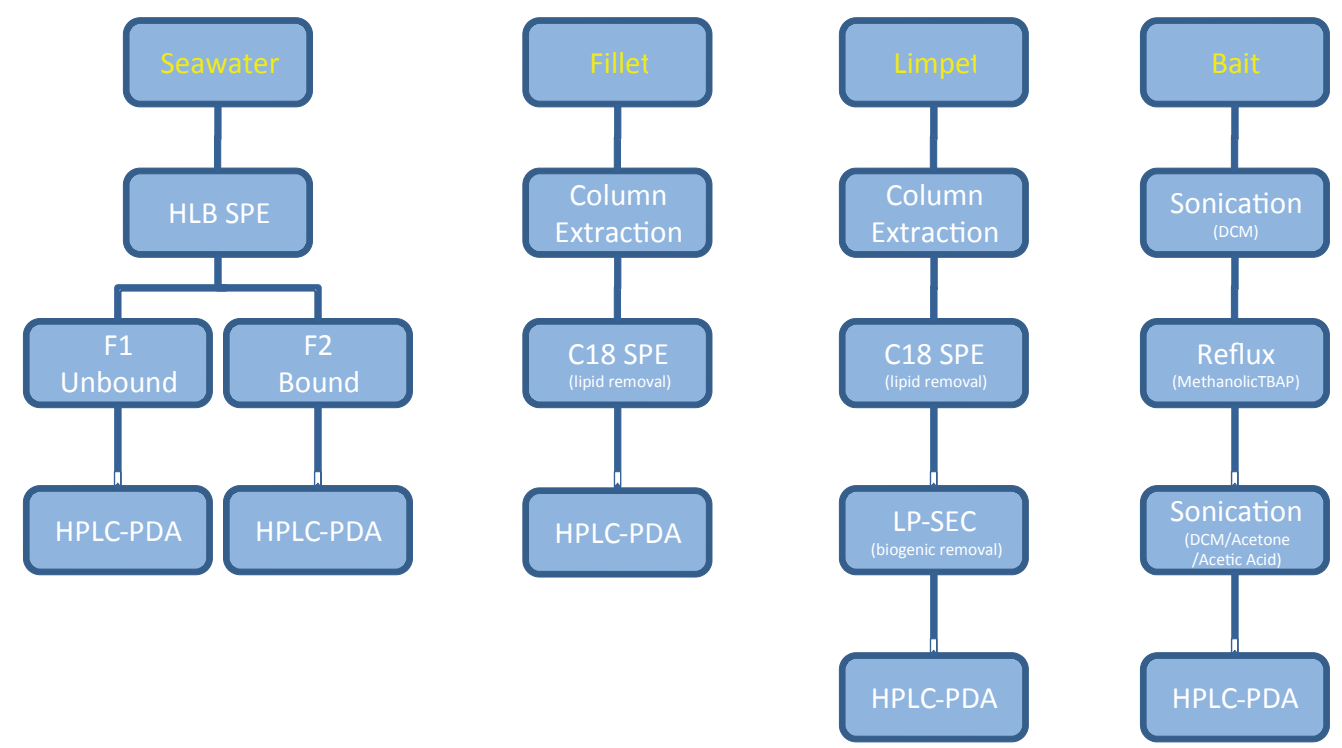

Figure 3. Preparatory methods for diphacinone in the various matrices.

$100 \mathrm{~mL}$ of aqueous Oceanic Natural Sea Salt solution and adding $2.5 \mu \mathrm{g}$ diphacinone. The final concentrations of the fortified reference sea-water samples and the Oceanic Natural Sea Salt water samples were 12.5 nanograms per milliliter $(\mathrm{ng} / \mathrm{mL})$ and $25 \mathrm{ng} / \mathrm{mL}$, respectively.

Oasis-HLB SPE cartridges were cleaned and preconditioned with $10 \mathrm{~mL}$ acetonitrile followed by $10 \mathrm{~mL}$ methanol at a flow rate of about $1 \mathrm{~mL} /$ minute and then dried under vacuum for about 3 minutes. Immediately before extraction, the SPE cartridge was conditioned with $10 \mathrm{~mL}$ aqueous TBAH-IP reagent followed by $20 \mathrm{~mL}$ of Milli-Q water, at about $1 \mathrm{~mL} /$ minute (cartridge remained wet). A $200 \mathrm{~mL}$ water sample $(100 \mathrm{~mL}$ for replicates, laboratory blanks, and laboratoryfortified samples) was applied to the cartridge at about $3 \mathrm{~mL} /$ minute. The sample container was rinsed quantitatively with about $20 \mathrm{~mL}$ Milli-Q water, which then was applied to the cartridge. Next, the cartridge was washed with $3 \mathrm{~mL}$ Milli$\mathrm{Q}$ water and dried under vacuum for about 3 minutes.

Diphacinone was recovered from the cartridge with $13 \mathrm{~mL}$ acetonitrile; the eluant was collected in a $15-\mathrm{mL}$ amber culture tube (fraction 1). Any more strongly bound diphacinone was recovered from the cartridge with $5 \mathrm{~mL}$ 70:30 (methanol:aqueous TBAH-IP reagent; volume:volume); this eluant was collected in a separate $15-\mathrm{mL}$ amber culture tube (fraction 2).

The first diphacinone eluants (fraction 1) were evaporated to dryness using nitrogen with a water bath temperature of $<50{ }^{\circ} \mathrm{C}$ (N-EVAP, Organomation, Inc., Berlin, Massachusetts). The residues were dissolved in 700 microliters $(\mu \mathrm{L})$ methanol, $300 \mu \mathrm{L}$ of the aqueous TBAH-IP reagent was added to match the liquid chromatography mobile phase, and $1 \mu \mathrm{g}$ coumarin (instrumental internal standard) was added. The residual diphacinone eluants (fraction 2) were fortified with $5 \mu \mathrm{g}$ coumarin and analyzed directly.

\section{Sample Preparation and Quantification of Diphacinone in Tissues}

Hunter and Sharp (1988) described the addition of ascorbic acid to the extraction solvent, as well as to the matrix before dehydration for extractions from vertebrate liver samples. This increased the recovery of indandione-group anticoagulant rodenticides in all of the liver samples tested. Before analysis of Mokapu field samples, it was established that ascorbic acid treatment was not required to achieve adequate recoveries of any diphacinone from the fish and limpet matrices. Further method development efforts established that a C18 SPE cleanup was necessary for fish fillet samples, whereas both C18 SPE and LP-SEC cleanup steps were necessary to remove residual lipid materials from the limpet matrix.

\section{Fish: Ta`ape, A`awa, and Hagi Fillets}

Fortified fish fillet samples were prepared in about $5 \mathrm{~g}$ of reference Ta ape matrix or sodium sulfate (procedural spikes) by adding $2.5 \mu \mathrm{g}$ diphacinone to the dehydrated reference material. The final concentration of the fortified matrix samples was 500 nanograms per gram $(\mathrm{ng} / \mathrm{g})$ wet-weight.

Homogenized Ta`ape (Lutjanus kasmira), A`awa (Bodianus bilunulatus), or Hagi (Sufflamen fraenatus) fillet tissue samples (5 g fish skinless fillet) were dehydrated with $25 \mathrm{~g}$ anhydrous sodium sulfate. The mixture was allowed to dehydrate at least 2 hours, and then was blended with stainless steel blades and a commercial blender until a free flowing powder was obtained.

The dehydrated sample was loaded into an extraction column with a total of about $20 \mathrm{~mL}$ of acetonitrile rinses of the sample container and then saturated with acetonitrile. The acetonitrile saturated dehydrated matrix was allowed to interact approximately 1 hour before extraction. Additional acetonitrile 
(150 mL) was added to the column, and the sample extracted at a flow rate of approximately $2 \mathrm{~mL} /$ minute until flow ceased; additional acetonitrile $(100 \mathrm{~mL})$ was added to the column, the extraction continued, and the eluant collected with the original extract. The extracts were rotary evaporated under vacuum $\left(<50{ }^{\circ} \mathrm{C}\right)$ to approximately $3 \mathrm{~mL}$, and quantitatively transferred to $15-\mathrm{mL}$ culture tubes with three sequential $2-\mathrm{mL}$ rinses with acetonitrile. The sample extracts were evaporated by nitrogen stream to $2 \mathrm{~mL}$ and mixed thoroughly.

Some co-extracted interferences (mainly lipid material) were removed by $\mathrm{C} 18 \mathrm{SPE}$. The cartridges were conditioned with $10 \mathrm{~mL}$ methanol followed by $10 \mathrm{~mL} 0.03 \mathrm{M}$ TBAH-IP, dried under vacuum for about 1 minute, and finally by rinsing with $10 \mathrm{~mL}$ acetonitrile (the cartridge remained wet). The $2 \mathrm{~mL}$ sample extracts were applied to the cartridge at about $2 \mathrm{~mL} / \mathrm{minute}$ (with three 1-mL acetonitrile rinses). Diphacinone was recovered from the cartridge with 7-mL acetonitrile (total acetonitrile $10 \mathrm{~mL}$ : three $1-\mathrm{mL}$ rinses plus $7 \mathrm{~mL}$ for elution). The eluant was collected in a $15-\mathrm{mL}$ amber culture tube.

The diphacinone eluants were evaporated to dryness with nitrogen. The residues were dissolved in $700 \mu \mathrm{L}$ methanol, $300 \mu \mathrm{L}$ of the aqueous TBAH-IP reagent was added to match the liquid chromatography mobile phase, and $1 \mu \mathrm{g}$ coumarin (instrumental internal standard) was added.

\section{Limpet: Whole Opihi}

Fortified samples were prepared with about $3 \mathrm{~g}$ of reference limpet matrix or sodium sulfate (procedural spikes) by adding $2.5 \mu \mathrm{g}$ diphacinone to the dehydrated reference material. The final concentration of the fortified matrix samples was $830 \mathrm{ng} / \mathrm{g}$.

Whole Opihi (Cellata exarata) limpet sample homogenates (about $3 \mathrm{~g}$ ) were dehydrated with $30 \mathrm{~g}$ anhydrous sodium sulfate. The mixture was allowed to dehydrate at least 2 hours, and then was blended with stainless steel blades and a commercial blender until a free flowing powder was obtained.

The dehydrated sample was loaded into an extraction column with a total of about $20 \mathrm{~mL}$ of acetonitrile rinses of the sample container and then saturated with acetonitrile. The acetonitrile saturated dehydrated matrix was allowed to interact approximately 1 hour before extraction. Additional acetonitrile $(150 \mathrm{~mL})$ was added to the column and the sample extracted at a flow rate of approximately $2 \mathrm{~mL} / \mathrm{minute}$ until flow ceased; additional acetonitrile $(100 \mathrm{~mL})$ was added to the column, the extraction continued, and the eluant collected with the original extract. The extracts were rotary evaporated under vacuum $\left(<50{ }^{\circ} \mathrm{C}\right)$ to approximately $3 \mathrm{~mL}$, and quantitatively transferred to $15-\mathrm{mL}$ culture tubes with three sequential 2-mL rinses with acetonitrile. The sample extracts were evaporated by nitrogen stream to $2 \mathrm{~mL}$ and mixed thoroughly.

Some co-extracted interferences (mainly lipid material) were removed by $\mathrm{C} 18 \mathrm{SPE}$. The cartridges were conditioned with $10 \mathrm{~mL}$ methanol followed by $10 \mathrm{~mL} 0.03 \mathrm{M}$ TBAH-IP, dried under vacuum for about 1 minute, and finally by rinsing with $10 \mathrm{~mL}$ acetonitrile (the cartridge remained wet). The
$2 \mathrm{~mL}$ sample extracts were applied to the cartridge at about $2 \mathrm{~mL} / \mathrm{minute}$ (with three $1-\mathrm{mL}$ acetonitrile rinses). Diphacinone was recovered from the cartridge with $7 \mathrm{~mL}$ acetonitrile (total acetonitrile $10 \mathrm{~mL}$ : three $1-\mathrm{mL}$ rinses plus $7 \mathrm{~mL}$ for elution). The eluant was collected in a $15-\mathrm{mL}$ amber culture tube.

The diphacinone eluants were evaporated to dryness with nitrogen. The residues were dissolved in $3 \mathrm{~mL}$ dichloromethane. Additional lipids and other biogenic material were removed by low-performance size-exclusion chromatography (SX-3 biobeads, dichloromethane mobile phase at a flow of $3.5 \mathrm{~mL} / \mathrm{minute}$ ). The diphacinone fractions (LP-SEC collect window from 40 to 60 minutes) were rotary evaporated under vacuum $\left(<50{ }^{\circ} \mathrm{C}\right)$ to approximately $3 \mathrm{~mL}$, and quantitatively transferred to $15-\mathrm{mL}$ culture tubes with three sequential $2-\mathrm{mL}$ rinses with dichloromethane. The dichloromethane sample extracts were evaporated to dryness with nitrogen. The residues were dissolved in $700 \mu \mathrm{L}$ methanol, $300 \mu \mathrm{L}$ of the aqueous TBAH-IP reagent was added to match the liquid chromatography mobile phase, and $1 \mu \mathrm{g}$ coumarin (instrumental internal standard) was added.

\section{Sample Preparation for Diphacinone in Ramik ${ }^{\circledR}$ Green Bait}

Primus and others (1998) described the extraction of diphacinone from steam rolled oat baits using $5 \mathrm{mM}$ methanolic tetrabutylammonium phosphate ion pairing solution. Mesmer and Flurer (2000) described the extraction of diphacinone by sonication of commercial indanedione rodenticides with methanol containing 2 percent formic acid. The extraction recovery of diphacinone from the Ramik® Green formulation was established in this study before analysis of field samples. The removal of co-extracted inert ingredients (green dye, waxes, etc.) using suitable SPE and other techniques also was investigated.

No reference material without active ingredient was available; therefore, no method quality-control samples were analyzed with the sample set. Instead, steps were taken to optimize extraction efficiency based on the nominal active ingredient concentration of diphacinone reported by the manufacturer in Ramik® Green bait (50 ppm).

Three composites of the bait samples were prepared containing two baits from each sample-lot submitted as follows: Lots 1, 2, and 3; Lots 4, 5, and 6; Lots 7, 8, 9, and 10. Two bait pellets were removed from each of the zip-lock bags, individual weights recorded, and the pellets were transferred to a ceramic mortar. The individual pellets were chopped into smaller pieces using a stainless steel knife, and the composite samples were ground to a fine powder using a ceramic pestle.

Approximately $2 \mathrm{~g}$ portions of each composite were weighed into $250-\mathrm{mL}$ boiling flasks, approximately $15 \mathrm{~mL}$ dichloromethane added, and the composites sonicated for 1 hour. Next, the dichloromethane extracted samples were extracted by reflux with $5 \mathrm{mM}$ methanolic tetrabutylammonium phosphate (TBAP; $55 \mathrm{~mL}$ ) for 8 hours. The extracts were 
filtered through Whatman 41 ashless filter paper with repeated rinses of the boiling flask with extraction solvent.

A second extraction was performed by soncating the post-refluxed composite bait samples with $15 \mathrm{~mL}$ dichloromethane:acetone:acetic acid (1:1:2\%; volume:volume:volume) for 2 hours to recover any residual diphacinone. This second extract was filtered with repeated rinses with the extraction solvent. Final volumes were adjusted to $100 \mathrm{~mL}$ (for the reflux extract) or $25 \mathrm{~mL}$ (for the sonicated extract) using the appropriate extraction solvent and the solutions were thoroughly mixed. Sub-samples of each of the first extracts $(2 \mathrm{~mL})$ and each of the second extracts $(10 \mathrm{~mL})$ were transferred to $15-\mathrm{mL}$ amber culture tubes.

The first and second extracts of the composite bait samples were evaporated individually to dryness with nitrogen. The residues were dissolved in $700 \mu \mathrm{L}$ methanol, $300 \mu \mathrm{L}$ of the aqueous TBAH-IP reagent was added to match the liquid chromatography mobile phase, and $1 \mu \mathrm{g}$ coumarin (instrumental internal standard) was added.

\section{Instrumental Analysis and Data Reduction}

\section{Final Sample Preparation}

As per previous discussion, all extracts were evaporated to approximately $3 \mathrm{~mL}$ by rotary evaporation and transferred to 15-mL screw capped amber culture tubes with three sequential 2-mL acetonitrile rinses. The concentrated extracts were evaporated to dryness by nitrogen evaporation and reconstituted in $700 \mu \mathrm{L}$ of methanol. Once the residues were dissolved, $300 \mu \mathrm{L}$ of $0.03 \mathrm{M}$ tetrabutylammonium hydroxide ion pair reagent (TBAP-IP) in water was added and mixed thoroughly. The samples were filtered through $0.45 \mu \mathrm{m}$ PTFE syringe filters directly in to $1-\mathrm{mL}$ amber autosampler vials.

\section{HPLC-PDA Analysis}

Quantification of diphacinone was performed with a Surveyor® HPLC system (Thermo-Fisher, Inc., San Jose, California), consisting of an autosampler, gradient pump, PDA detector, and XCalibur ${ }^{\circledR}$ chromatography data collection and processing software. A Luna ${ }^{\circledR}$ C18(2) $100 \AA$, 150 x 2 millimeter (mm) x $3 \mu \mathrm{m}$ analytical column with a SecurityGuard® C18 guard column cartridge (Phenomenex. Torrance, California) was used for the separation of diphacinone. The ion-pair reagent for the mobile phase was $0.03 \mathrm{M} \mathrm{TBAH-}$ IP in water adjusted to a $\mathrm{pH}$ of 6.0 using $2 \mathrm{~N} o$-phosphoric acid. The mobile phase, methanol/0.03 M TBAH-IP (70:30 volume:volume), was delivered isocratically at $0.8 \mathrm{~mL} / \mathrm{minute}$. The sample was applied onto the column via $20 \mu \mathrm{L}$ full-loop injections. Diphacinone was detected by wavelength scanning from 230 to 400 nanometers $(\mathrm{nm})$ with quantification at the primary wavelength $(286 \mathrm{~nm})$ and confirmation at the two secondary wavelengths (314 and $326 \mathrm{~nm}$ ). The primary wavelength for the instrumental internal standard, coumarin was $276 \mathrm{~nm}$ with a secondary wavelength of $312 \mathrm{~nm}$. A diphacinone standard chromatogram is shown in figure 4; a photodiode array detector spectrum is shown in figure 5. Calibration of the instrument was achieved through a range of standards from just above the limit of quantification of about $10 \mathrm{ng} / \mathrm{mL}$ to $5,000 \mathrm{ng} / \mathrm{mL}$ diphacinone [and coumarin].

\section{Quality Assurance and Quality Control}

All research was conducted in accordance with the USGS Quality Assurance Plan, a system of checks managed by a Quality-Assurance system that assures that defined standards of quality are being met (at stated levels of confidence). The objective of the quality assurance plan for this study was to assure that the analytical and/or biochemical analyses provided accurate and precise measurements of the samples collected in this study. The general scheme included replication of various stages (table 2), comparison and calibration against known standards, proper maintenance and calibration of equipment, accurate sample tracking and custody, proper documentation at all steps of sample processing, and other considerations of Good Laboratory Practice.

The accuracy and precision of analytical methods for this study was assessed by the following checks of sample preparation and instrumental analysis: replicated sample or reference matrices, procedural blanks, fortified procedural samples, negative control (reference) matrix blanks, and fortified negative control matrix samples. The fortified matrix samples were amended with native analyte(s) during sample preparation. The numbers of quality control samples of each type are presented in table 3 .

\section{Sea Water Holding Time}

Because of questions related to the storage of seawater samples (dark, refrigerated at $4{ }^{\circ} \mathrm{C}$ ), a stability check experiment was conducted to determine the feasibility of the approximately 50 day holding time from sample collection (February 17, 2008), shipping to the USGS (March 17, 2008), and subsequent analysis (April 10, 2008).

\section{Negative Control Bait Matrix}

The lack of a reference bait material without active ingredient limited the quality control samples to be analyzed with the bait sample set. Steps were taken to maximize extraction efficiency, based on the manufacturer's nominal active ingredient concentration of 50 ppm diphacinone in Ramik ${ }^{\circledR}$ Green bait.

\section{Criteria for Quantification of HPLC-PDA Data}

Method limits of detection (LOD) and limits of quantification (LOQ) were estimated from low-level standards and 


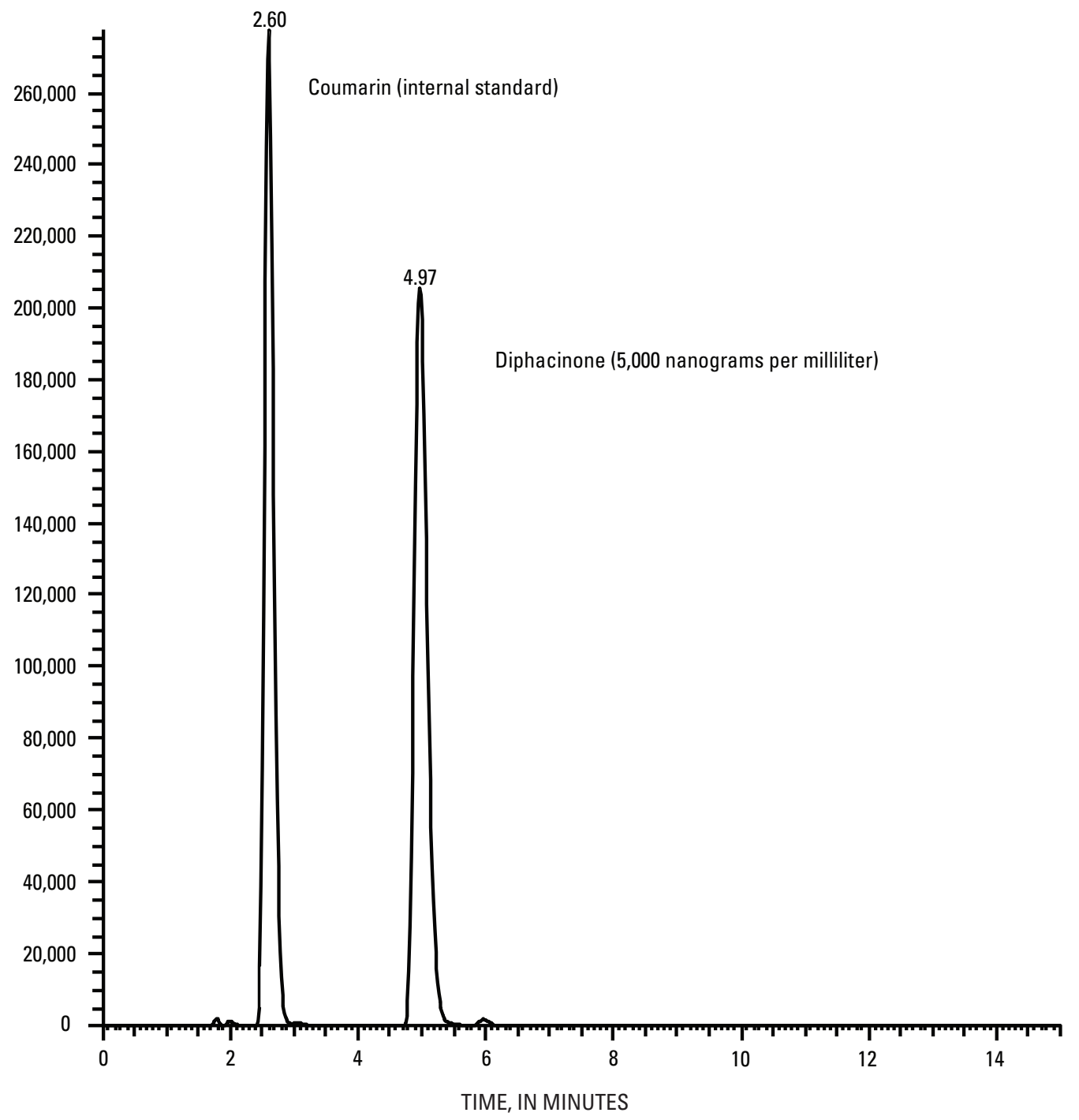

Figure 4. High performance liquid chromatography-photodiode array (HPLC-PDA) chromatogram of diphacinone (wavelength range 230 to 400 nanometers).

determined by the signal-to-noise ratio of the peak. Keith and others $(1983 ; 1991)$ established the LOD as 3 times the background signal, and the LOQ as 10 times background signal. For the positive identification and quantification of each analyte, the following criteria were established:

1. The analyte peak area must be greater than 10 times background signal (LOQ) for quantification, or 3 times background signal (LOD) to be considered detected, but $<\mathrm{LOQ}$. If a peak is not present, or is less than three times background signal, it will be considered "Not Detected".

2. The analyte elution must occur at retention times that are equivalent to those for the corresponding calibration standards (within \pm 3 seconds or $<1$ percent difference, as established by the method validation).

3. The spectrum of an unknown analyte must be comparable to the spectrum of a corresponding calibration standard (within purity factors established by the method validation and the expertise of the analyst).

\section{Acceptance or Rejection Criteria for Results}

Background responses from procedural and matrix blanks were quantified and used to estimate method limits of detection and quantification. Acceptable recoveries of spiked samples were determined by diphacinone methods development studies as 50 to 150 percent.

\section{Results}

Final analytical results were adjusted using the response of the instrumental internal standard and then adjusted for any 


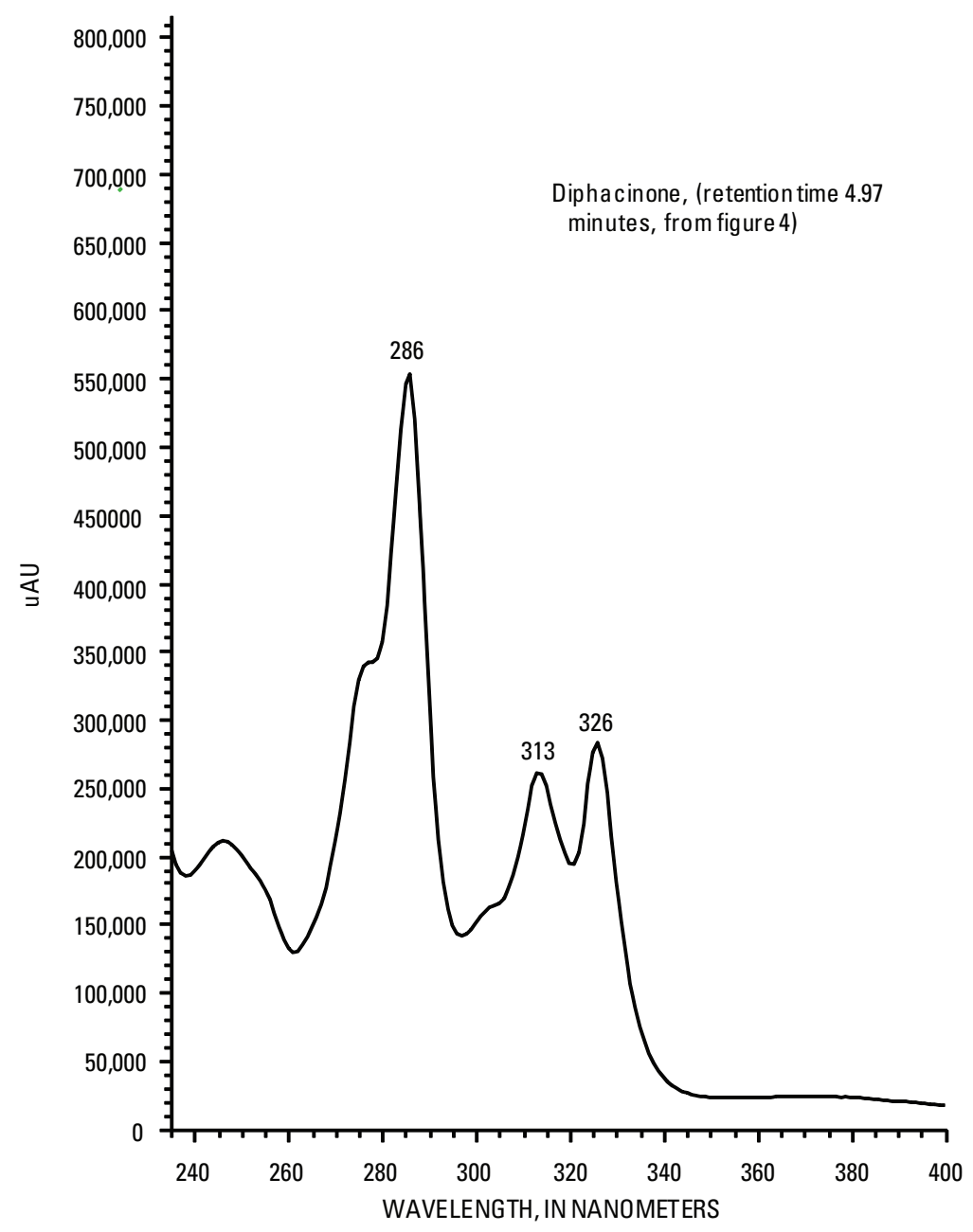

Figure 5. Photodiode array (PDA) spectrum of diphacinone.

background levels of analytes by subtraction of mass-weighted procedural blank amounts. Similarly, matrix spike recoveries were estimated after any necessary corrections.

The sample preparation methods increased in their complexity as the complexity of the sample matrices increased, generally in the order: sea water $<$ fillet $<$ limpet. Preparation of bait composite samples required strong and specific reaction conditions to completely release diphacinone bound in the bait matrix and the wax-like coating materials. The efficiency and selectivity of the preparatory methods that were developed for this study was reflected in the achievement of consistently low detection limits without background interferences for all matrices.

\section{Sea Waters}

The concentrations of diphacinone in Mokapu Island sea-water samples were below the LOD determined for this matrix and method (table 4). The LOD was $90 \mathrm{ng} / \mathrm{L}$ (or parts per trillion), and the LOQ was $270 \mathrm{ng} / \mathrm{L}$, based on a sea-water sample volume of $200 \mathrm{~mL}$ with typical background, according to the methods of Keith et al. $(1983 ; 1991)$. Fraction 1 contained greater than 98 percent of the diphacinone in fortified sea-water samples. The instrumental internal standard (coumarin) response ranged from 96 to 108 percent of standards. Instrumental blanks, procedural blanks, and negative control samples for the sea water analyses did not have any detectable concentrations of diphacinone.

\section{Fish Fillets}

The concentrations of diphacinone in Mokapu Island Ta`ape, A'awa, and Hagi skinless fillet samples were below the LOD [table 5; 10 nanograms per gram (ng/g), or ppb]. The instrumental internal standard (coumarin) responses ranged from 96 to 104 percent. Instrumental blanks, procedural 
Table 2. Quality-control sample types for analysis of environmental samples.

\begin{tabular}{lc}
\hline \multicolumn{1}{c}{ Sample type } & \multicolumn{1}{c}{ Quality-control function } \\
\hline Procedural blank & Determines analyte laboratory background levels or background \\
& interferences with analyte signal. \\
Negative control material (Matrix blank) & $\begin{array}{c}\text { Determines background interferences with analyte signal related to a } \\
\text { representative and controllable sample matrix. }\end{array}$ \\
Fortified negative control material (Matrix spike) & Determines analyte recovery and assesses potential signal enhance- \\
& ment or suppression from a representative and controllable sample \\
& matrix. \\
Replicate sample—-within set & Determines repeatability analyte signal associated with a specific \\
& environmental matrix. \\
Replicate sample-between sets & Determines the reproducibility of analyte signal associated with a \\
& specific environmental matrix. \\
Positive control material & Determines analyte recovery and assesses potential signal enhance- \\
& ment or suppression from a representative and controllable sample \\
& matrix on an ongoing basis within or between laboratories. \\
\hline
\end{tabular}

Table 3. Quality-control sample types and levels selected for study.

[--, not applicable]

\begin{tabular}{|c|c|c|c|c|}
\hline \multirow[b]{2}{*}{ Sample type } & \multicolumn{4}{|c|}{ Quality-control level (number of samples) } \\
\hline & Sea water & Fish fillet & Whole limpet & Ramik ${ }^{\circledR}$ Green Bait \\
\hline Mock fortification solutions & 1 & 1 & 1 & 1 \\
\hline Procedural blanks & 1 & 1 & 1 & 1 \\
\hline Fortified procedural blanks & -- & 1 & 1 & 1 \\
\hline $\begin{array}{l}\text { Negative control (reference) } \\
\text { matrices }\end{array}$ & 1 & 1 & 1 & -- \\
\hline $\begin{array}{l}\text { Fortified negative control } \\
\text { (reference) matrices }\end{array}$ & 1 & 1 & 1 & -- \\
\hline $\begin{array}{l}\text { Replicate samples within } \\
\text { set }\end{array}$ & 3 & 3 & 3 & 3 \\
\hline Total & 7 & 8 & 8 & 6 \\
\hline
\end{tabular}


Table 4. Diphacinone concentrations in sea water.

[USGS, U.S. Geological Survey; ID, identification; ng/L, nanogram per liter (part per trillion, pptr); <, less than; ND, not detected; --, not applicable]

\begin{tabular}{|c|c|c|c|c|}
\hline $\begin{array}{l}\text { USGS } \\
\text { ID }\end{array}$ & Field label & pH & $\begin{array}{c}\text { Diphacinone } \\
\text { (ng/L) }\end{array}$ & $\begin{array}{l}\text { Recovery } \\
\text { (percent) }\end{array}$ \\
\hline 42033 & $\begin{array}{l}\text { Kalaupapa National Historical Park Ka Laea Point, } \\
\text { Molokai }\end{array}$ & 8.10 & $<90(\mathrm{ND})$ & -- \\
\hline 42036 & Mokapu Station 1 & 8.20 & $<90(\mathrm{ND})$ & -- \\
\hline 42037 & Mokapu Station 2 & 8.17 & $<90(\mathrm{ND})$ & -- \\
\hline 42038 & Mokapu Station 3 & 8.10 & $<90(\mathrm{ND})$ & -- \\
\hline 42039 & Mokapu Station 4 & 8.21 & $<90(\mathrm{ND})$ & -- \\
\hline 42040 & Mokapu Station 5 & 8.16 & $<90(\mathrm{ND})$ & -- \\
\hline $42041-1$ & Mokapu Station 6-replicate 1 & 8.17 & $<90(\mathrm{ND})$ & -- \\
\hline $42041-2$ & Mokapu Station 6-replicate 2 & 8.17 & $<90(\mathrm{ND})$ & -- \\
\hline \multirow[t]{4}{*}{$42041-3$} & Mokapu Station 6-replicate 3 & 8.17 & $<90(\mathrm{ND})$ & -- \\
\hline & HPLC blank & -- & $<90(\mathrm{ND})$ & -- \\
\hline & SPE blank & -- & $<90(\mathrm{ND})$ & -- \\
\hline & Procedural blank & -- & $<90(\mathrm{ND})$ & -- \\
\hline \multirow[t]{2}{*}{42033} & $\begin{array}{l}\text { Negative control (reference) sea water blank } \\
\text { Kalaupapa National Historical Park }\end{array}$ & 7.96 & $<90(\mathrm{ND})$ & -- \\
\hline & Fortified procedural Ocean Sea Salt solution & 7.96 & -- & 88 \\
\hline 42033-fortified & $\begin{array}{l}\text { Fortified negative control (reference) sea water } \\
\text { Kalaupapa National Historical Park }\end{array}$ & 8.11 & -- & 86 \\
\hline
\end{tabular}


Table 5. Diphacinone concentrations in fish fillets.

[USGS, U.S. Geological Survey; ID, identification; ng/g, nanogram per gram (part per billion, ppb); values reported on a wet-tissue weight basis; <, less than; ND, not detected; --, not applicable]

\begin{tabular}{|c|c|c|c|c|}
\hline $\begin{array}{l}\text { USGS } \\
\text { ID }\end{array}$ & Field label & Sample type & $\begin{array}{c}\text { Diphacinone } \\
\text { (ng/g) }\end{array}$ & $\begin{array}{l}\text { Recovery } \\
\text { (percent) }\end{array}$ \\
\hline 42035 & Oahu Commercial Fish Market & Blue-lined Snapper, Ta`ape (Lutjanus kasmira) & $<10(\mathrm{ND})$ & -- \\
\hline $42046-1$ & Mokapu Station 1-B—replicate 1 & Blue-lined Snapper, Ta`ape (Lutjanus kasmira) & $<10(\mathrm{ND})$ & -- \\
\hline $42046-3$ & Mokapu Station 1-B—replicate 3 & Blue-lined Snapper, Ta`ape (Lutjanus kasmira) & $<10$ (ND) & -- \\
\hline 42047 & Mokapu Station 1-C & Blue-lined Snapper, Ta`ape (Lutjanus kasmira) & $<10(\mathrm{ND})$ & -- \\
\hline 42048 & Mokapu Station 1-D & Blue-lined Snapper, Ta`ape (Lutjanus kasmira) & $<10(\mathrm{ND})$ & -- \\
\hline 42050 & Procedural blank & & $<10(\mathrm{ND})$ & -- \\
\hline \multirow[t]{2}{*}{42035} & Negative control Ta`ape (reference) & Blue-lined Snapper, Ta`ape (Lutjanus kasmira) & $<10(\mathrm{ND})$ & -- \\
\hline & Fortified procedural sample & & -- & 102 \\
\hline 42035-fortified & $\begin{array}{l}\text { Fortified negative control Ta`ape } \\
\quad \text { (reference) }\end{array}$ & Blue-lined Snapper, Ta`ape (Lutjanus kasmira) & -- & 100 \\
\hline
\end{tabular}


blanks, and negative control (reference) samples for the fish fillet analyses did not have any detectable concentrations of diphacinone.

The performance throughout the method was monitored by fortified procedural samples and fortified reference Ta`ape matrix samples. No diphacinone residues were detected in the procedural blanks or reference Ta`ape samples. Method recoveries ranged from 100 to 102 percent.

\section{Limpets}

The concentrations of diphacinone in Mokapu Island limpet (whole body Opihi) samples were below the LOD (table 6; $17 \mathrm{ng} / \mathrm{g}$ ). The instrumental internal standard (coumarin) responses ranged from 99 to 101 percent. Instrumental blanks, procedural blanks, and negative control (reference) samples for the whole Opihi limpet analyses did not have any detectable concentrations of diphacinone.

The performance throughout the method was monitored by fortified procedural samples and fortified field Opihi limpet matrix. No diphacinone residues were detected in the procedural or reference Opihi blanks. Method recovery was
102 percent for the fortified procedural samples and the fortified Opihi sample.

\section{Ramik ${ }^{\circledR}$ Green Diphacinone Bait Pellets}

The concentrations of diphacinone in the three composited lots of Ramik® Green baits used for the Mokapu Island rat eradication study were determined to contain from 44 to 46 $\mu \mathrm{g} / \mathrm{g}(\mathrm{ppm})$ diphacinone as determined by this methodology (table 7). The LOD and LOQ were not established because negative control bait (without diphacinone) was unavailable. The nominal concentration for the baits as reported by the manufacturer was $50 \mu \mathrm{g} / \mathrm{g}$ (ppm); thus, the concentrations of diphacinone in composited lots of baits ranged from 88 to 92 percent of the nominal concentration. The amount of diphacinone recovered by reflux extraction averaged 99.4 percent of the total extractable diphacinone determined by combined reflux and sonication extraction steps. The instrumental internal standard (coumarin) responses ranged from 97 to 99 percent.

Table 6. Diphacinone concentrations in whole Opihi limpets.

[USGS, U.S. Geological Survey; ID, identification; ng/g, nanogram per gram (part per billion, ppb); values reported on a wet-tissue weight basis; <, less than; ND, not detected; --, not applicable]

\begin{tabular}{|c|c|c|c|c|}
\hline USGS ID & Field label & Sample description & $\begin{array}{l}\text { Diphacinone } \\
\text { (ng/g) }\end{array}$ & $\begin{array}{l}\text { Recovery } \\
\text { (percent) }\end{array}$ \\
\hline 42034 & $\begin{array}{l}\text { Kalaupapa National Historical } \\
\text { Park Ka Laea Point, Molokai }\end{array}$ & $\begin{array}{l}\text { Limpet, Opihi (Cellata } \\
\text { exarata) }\end{array}$ & $<17(\mathrm{ND})$ & -- \\
\hline 42042 & Mokapu Station 1 & $\begin{array}{l}\text { Limpet, Opihi (Cellata } \\
\text { exarata) }\end{array}$ & $<17$ (ND) & -- \\
\hline 42043 & Mokapu Station 2 & $\begin{array}{l}\text { Limpet, Opihi (Cellata } \\
\text { exarata) }\end{array}$ & $<17(\mathrm{ND})$ & -- \\
\hline 42044-1 & Mokapu Station 3-replicate 1 & $\begin{array}{l}\text { Limpet, Opihi (Cellata } \\
\text { exarata) }\end{array}$ & $<17$ (ND) & -- \\
\hline $42044-2$ & Mokapu Station 3-replicate 2 & $\begin{array}{l}\text { Limpet, Opihi (Cellata } \\
\text { exarata) }\end{array}$ & $<17(\mathrm{ND})$ & -- \\
\hline \multirow[t]{5}{*}{$42044-3$} & Mokapu Station 3-replicate 3 & $\begin{array}{l}\text { Limpet, Opihi (Cellata } \\
\text { exarata) }\end{array}$ & $<17(\mathrm{ND})$ & -- \\
\hline & $\begin{array}{l}\text { Fortified C18 SPE procedural } \\
\text { sample }\end{array}$ & & & 99 \\
\hline & $\begin{array}{l}\text { Fortified LP-SEC procedural } \\
\text { sample }\end{array}$ & & & 100 \\
\hline & Procedural blank & & $<17(\mathrm{ND})$ & -- \\
\hline & Fortified procedural sample & & -- & 102 \\
\hline 42034-fortified & Fortified field Opihi (reference) & $\begin{array}{l}\text { Limpet, Opihi (Cellata } \\
\text { exarata) }\end{array}$ & -- & 102 \\
\hline
\end{tabular}


Table 7. Diphacinone concentrations in Ramik® Green bait lot composites.

[USGS, U.S. Geological Survey; ID, identification; $\mu \mathrm{g} / \mathrm{g}$, microgram per gram (part per million, ppm); values reported on an as-received weight basis]

\begin{tabular}{cccc}
\hline $\begin{array}{c}\text { USGS } \\
\text { Composite ID }\end{array}$ & Field label & \multicolumn{1}{c}{ Sample type } & $\begin{array}{c}\text { Diphacinone } \\
(\boldsymbol{\mu g} / \mathbf{g})\end{array}$ \\
\hline $42051 / 42052 / 42053$ & Maui-1/-2/-3 & $\begin{array}{c}\text { Ramik® Green (diphacinone bait } \\
\text { pellets) }\end{array}$ & 44 \\
$42054 / 42055 / 42056$ & Maui-4/-5/-6 & $\begin{array}{c}\text { Ramik® Green (diphacinone bait } \\
\text { pellets) } \\
\text { Ramik® Green (diphacinone bait } \\
\text { pellets) }\end{array}$ & 45 \\
\hline
\end{tabular}

\section{Conclusions}

The analytical part of this study demonstrated that there were no matrices that contained diphacinone at or above the method limit of detection, which ranged from about 50 to 90 parts per trillion (nanograms per liter) for sea-water samples, or from about 10 to 17 parts per billion (nanograms per gram) for tissue samples. The methods developed were satisfactory, with negligible background interferences being encountered and efficient recoveries of diphacinone, which ranged from about 86 to 102 percent in fortified matrix samples.

Concentrations of diphacinone, the active ingredient, in Ramik@ Green bait samples, averaged 45 micrograms per gram (parts per million), which was 90 percent of the nominal concentration. Refluxing for 8 hours with methanolic solutions of the tetrabutylammonium phosphate (TBAP) ion-pairing reagent was required for efficient recovery of diphacinone from the bait samples.

For quality control, confirmation of peak identity and purity was made by comparing the retention times and peak spectra to diphacinone standards. All samples with diphacinone concentrations less than the limit of detection did not have peaks that matched the retention times or spectra of diphacinone standards. Additionally, the area ratios of the primary and secondary quantitation wavelengths did not correspond to known diphacinone standards, with the exception of diphacinone fortified quality-control samples

The isolation, concentration, and high performance liquid chromatography-photodiode array (HPLC-PDA) method performed well throughout the analyses of all sample matrices (sea water, fish fillet, whole limpet, and Ramik ${ }^{\circledR}$ Green bait samples). No instances of interfering compounds co-eluting with diphacinone (or with coumarin) were noted. The co-elution of compounds that interfere with analyte response (quantitation) or analyte spectra (identification) typically results in reporting an analyte as not quantifiable at an increased limit of quantification.

\section{Acknowledgements}

The authors thank Peter Dunlevy (USDA-APHIS-WS) and Cathrine Swift (USFWS) for their contributions in this effort. They have made the primary selection of the study area, and continued to work on logistics, sampling, site assessment, and other aspects of this study.

\section{References}

Hunter, K. and Sharp, E.A., 1988, Modification to procedures for the determination of chlorophacinone and for multiresidue analysis of rodenticides in animal tissue: Journal of Chromatography A, v. 437, p. 301-305.

Keith, L.H., Crummet, W., Deegan, J., Jr., Libby, R.A., Taylor, J.K., and Wentler, G.,1983, Principles of environmental analysis: Analytical Chemistry, v. 55, p. 2,210-2,218.

Keith, L.H., 1991, Environmental sampling and analysis-A practical guide: Boca Raton, Fla., Lewis Publishers, Inc., $143 \mathrm{p}$.

Mesmer, M.Z., and Flurer, R.A., 2000, Determination of chlorophacinone and diphacinone in commercial rodenticides by liquid chromatography-UV detection and liquid chromatography-electrospray ionization mass spectrometry: Journal of Chromatography A, v. 89, p. 249-255.

Primus, T.M., Griffin, D.L., Volz, S.A., and Johnston, J.J., 1998, Reversed-phase ion-pair liquid chromatographic determination of chlorophacinone and diphacinone in steam-rolled oat baits and steam-rolled oat/wax baits: Journal of the Association of Official Analytical Chemists International, v. 81, p. 349-357.

Swenson, C., and Duvall, F.P., II, 2007, Draft environmental assessment-Eradication of Polynesian rats (Rattus exulans) from Mokapu and Alau Islands, Hawai'i. accessed April 18, 2008, at URL: www.fws.gov/pacificislands/ FinalEAMokapuRatEradication.pdf 
U.S. Environmental Protection Agency, 1998, Reregistration Eligibility Decision (RED)—Rodenticide Cluster: EPA

738-R-98-007.

Yang, S.Y., Pan, G.M., Meng, G.F., Zhang, D.M., 2001, Study of diphacinone in biological samples by high performance liquid chromatography/diode array detection: Separations and Purifications, v. 19, p. 245-247.

Publishing support provided by:

Rolla Publishing Service Center

For more information concerning this publication, contact:

Director, USGS Columbia Environmental Research Center

4200 New Haven Road

Columbia, M0 65201

(573) 875-5399

Or visit the Columbia Environmental Research Center Web site at: http://www.cerc.usgs.gov 

훙.

음

음

s.

음

음

ํㅗㅇ

옴

을

흐

총

3

흥.

족

ֻ

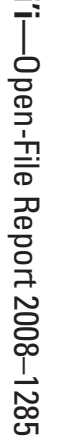

